\title{
Modeling the kinetics of peroxidase inactivation, colour and texture changes of Portuguese cabbage (Brassica oleracea L. var. costata DC) during UV-C light and heat blanching
}

\author{
Rui M. S. Cruz ${ }^{\mathrm{a}, \mathrm{b}}$, Ana I. A. Godinho ${ }^{\mathrm{a}}$, Dilek Aslan ${ }^{\mathrm{c}}$, Necip F. KoçaK ${ }^{\mathrm{c}}$, And \\ MARGARIDA C. VIEIRA ${ }^{\mathrm{a}, \mathrm{b}^{*}}$ \\ ${ }^{a}$ Department of Food Engineering, Institute of Engineering, University of Algarve, Campus da Penha, \\ 8005-139 Faro, Portugal \\ b MeditBio- Center for Mediterranean Bioresources and Food, University of Algarve, Campus de Gambelas, \\ 8005-139 Faro, Portugal \\ ${ }^{\mathrm{c}}$ Department of Food Engineering, University of Gaziantep. Gıda Mühendisliği Bölümü, 27310 Gaziantep, \\ Turkey \\ ${ }^{*}$ Corresponding author \\ mvieira@ualg.pt \\ TEL: +351-289-800151 \\ FAX: $+351-289-888405$
}

Received: 29 February 2016; Published online: 18 October 2016

\begin{abstract}
The effects of heat blanching and UV-C light followed by heat on Portuguese cabbage peroxidase (POD), colour and texture were studied in the temperature range of $80-95{ }^{\circ} \mathrm{C}$. POD inactivation, lightness $(L)$ and yellowness $(b)$ colour changes were described by a first-order reaction model. The greenness $(a)$ colour and texture (firmness) changes followed a two fraction kinetic model behaviour. The temperature effect was well described by the Arrhenius law.

At lower temperatures the combined treatment showed higher POD inactivation. Colour and texture parameters did not show significant differences between treatments. Long processing times turned the leaves slightly darker, decreased greenness, yellowness and firmness. Short processing times increased the firmness and greenness of the leaves. The treatment at $80{ }^{\circ} \mathrm{C}$ for 90 seconds reduced $90 \%$ of POD, retaining $98 \%$ of lightness and $92 \%$ of yellowness and improved the green colour $(130 \%)$ and firmness (125\%). At $80{ }^{\circ} \mathrm{C}$ the heat blanching required $7.4 \mathrm{~min}$ to inactivate $90 \%$ of the enzyme activity, reducing lightness, greenness, yellowness and firmness to $92 \%, 68 \%, 62 \%$ and $61 \%$, respectively. The present findings will help to optimize the Portuguese cabbage blanching conditions.
\end{abstract}

Keywords: Portuguese cabbage; Blanching; UV-C light; Peroxidase; Colour; Texture

\section{Introduction}

Portuguese cabbage (Brassica oleracea L. var. costata DC) is a very popular cabbage in Portugal together with galega cabbage, all very rich in vitamins and mineral salts, being the major ingredient in the traditional kale soup and in the "cozido à portuguesa" (traditional dish consist- ing of boiled cabbage with sausages, beef and pork). This cabbage is a perishable product and the application of a freezing process could be a good solution to extend its shelf-life. Many fruits and vegetables are blanched (e.g. immersion in hot water for a short time) before any freezing process, to inactivate oxidative enzymes. Peroxidase (POD) is one of them and acts on the hy- 
drogen peroxide $\left(\mathrm{H}_{2} \mathrm{O}_{2}\right)$ present in the cell, leading to oxidation of several cellular compounds, thus causing changes of colour and flavour in vegetables (Nagodawithana \& Reed, 1993). Due to its resistance to thermal treatment, POD is often used as a blanching indicator (Ganjloo, Rahman, Osman, Bakar, \& Bimakr, 2011; Szymanek, 2011).

The blanching process has proved to be one of the most effective processes to clean the surface of vegetables, destroy microorganisms and inactivate enzymes. On the other hand, blanching may also cause off-flavours, off-colours, changes in texture, vitamins and minerals (Patras, Tiwari, \& Brunton, 2011). Moreover, from an industrial point of view, this process may be extremely water and energy consuming (Aguilar, Rodriguez-Herrera, Montanez-Saenz, Reyes-Vega, \& Contreras-Esquivel, 2004). Nonthermal treatments, aimed at reducing microbial content or enzyme activity, while retaining the quality of the product, are promising alternative technologies in food processing. An emerging and challenging technology that can be used by the food industry is the application of ultraviolet (UV) radiation (Allende \& Artes, 2003). Low intensity light treatments may modify the conformation of the enzyme active site without changing its catalyzing capacity but leading to an increase of the overall activity. On the other hand, enzyme inactivation may be the result of nonreversible structural changes due to higher intensity light treatments (Manzocco, Dri, \& Quarta, 2009). Perhaps the weakest point of UV-C light is its poor penetrative capacity, therefore this technique is limited to food surface applications. Nevertheless, the application of physical factors, such as temperature and/or pressure, combined with UV-C light, may result in the increase of the enzymatic activity, followed by further inactivation. These techniques used in combination (or sequentially), normally referred to as hurdle technologies, have been used as less severe heat treatments, resulting in higher quality and safer products than traditional treatments (Manzocco, Dri, \& Quarta, 2009). Moreover, UV-C light has a positive image to the consumer and is considered a low cost non-thermal technology (Koutchma, 2009).

On the basis of these considerations and the few studies available in the literature reporting the effect of blanching treatments on cabbage leaves (Alvarez-Jubete, Valverde, Patras, Mullen, \& Marcos, 2014; Jaiswal, Gupta, \& Abu-Ghannam, 2012), the aim of this work was to evaluate the kinetics of Portuguese cabbage POD inactivation, colour and texture changes during heat blanching and an alternative blanching process (UV-C light followed by heat blanching) and with the findings help to optimize the Portuguese cabbage blanching conditions.

\section{Materials and Methods}

\subsection{Sample preparation}

Portuguese cabbage was purchased at a local market in Faro, Portugal. The leaves were selected and the tip of each leaf was cut and then weighed (11 g).

\subsection{Heat blanching and combined treatment processes}

The samples were separated in two groups according to the treatment to be applied: UV-C light followed by heat blanching group and the heat blanching group. The first group was exposed to a UV-C radiation intensity of $11 \mathrm{Wm}^{-2}$ for $90 \mathrm{~s}$ (each leaf side) at $25 \pm 1{ }^{\circ} \mathrm{C}$ in a ventilated UV-C chamber (composed of four UV lamps (Philips TUV G8T5 $8 \mathrm{~W}$, Holland), each separated by $10 \mathrm{~cm}$ ). The lamps were placed at $21.5 \mathrm{~cm}$ above the processing surface. During UV-C radiation processing, lab coats, protective gloves and safety goggles were worn by staff. UV-C radiation intensity was determined by a photo-radiometer (Delta OHM DO 9721, Caselle di Selvazzano, Italy) and an irradiance probe (Delta OHM LP 9021 UVC, Caselle di Selvazzano, Italy). Then, both groups were immersed in an $8 \mathrm{~L}$ water bath (Grant W14, Cambridgeshire, England), with temperatures ranging from 80 to $95{ }^{\circ} \mathrm{C}$ for different periods of exposure (up to $480 \mathrm{~s}$, based in preliminary tests for peroxidase inactivation). After the thermal treatments, the leaves were cooled down in an iced water bath. The temperature was monitored by a digital thermometer (Ellab ctd 87,

\begin{tabular}{l|l|l|l} 
IJFS | October 2016 | Volume 5 & pages 180-192
\end{tabular} 
Roedovre, Denmark) and a thermocouple (1.2 $\mathrm{mm}$ needle dia.; constantan-type $\mathrm{T}$ ). The experiments were run in triplicate.

\subsection{Peroxidase determination}

\section{Peroxidase extraction}

Leaves $(3 \mathrm{~g}$ ) were added to $100 \mathrm{ml}$ of potassium phosphate buffer solution, previously prepared with distilled water and mono and dipotassium phosphate (Merck) with a molar concentration of $0.1 \mathrm{M}, \mathrm{pH} 6.5$ and kept at $4{ }^{\circ} \mathrm{C}$ (according to the method of (Morales-Blancas, Chandia, \& Cisneros-Zevallos, 2002), and homogenized for 1 minute with an Ultra-Turrax (IKA T25 Janke \& Kunkel, Staufen, Germany). The suspension was then centrifuged in polypropylene tubes for 10 minutes at $18,000 \times \mathrm{g}$ (Sigma $3 \mathrm{~K} 20$, Osterode, Germany) and $4{ }^{\circ} \mathrm{C}$. The POD enzymatic extract was then filtered through filter paper Whatman $\mathrm{n}^{\mathrm{o}} 1$.

\section{Peroxidase activity measurement}

The POD activity was determined by mixing $0.120 \mathrm{ml}$ of enzymatic extract and $3.48 \mathrm{ml}$ of substrate solution in $10 \mathrm{~mm}$-path-length glass cuvettes (Amersham Bioscience). The substrate solution was prepared daily (mixture of $0.1 \mathrm{ml}$ of guaiacol (BDH Chemicals Ltd) (99.5\%), 0.1 $\mathrm{ml}$ of hydrogen peroxide (Pancreac) $(30 \%)$ and $99.8 \mathrm{ml}$ of potassium phosphate buffer $(0.1 \mathrm{M}$, $\mathrm{pH}$ 6.5)). The POD activity was measured by absorbance increase using an UV/Vis spectrophotometer (Hitachi U-2000, Tokyo, Japan) at $6 \mathrm{~s}$ intervals and $470 \mathrm{~nm}$ (absortivity $\xi=26.6 \mathrm{mM}^{-1}$ $\mathrm{cm}^{-1}$ for tetraguaiacol). The reaction was followed until steady state was reached using a blank prepared with $0.120 \mathrm{ml}$ of distilled water and $3.48 \mathrm{ml}$ of substrate solution.

\section{Protein determination}

The protein content was determined by Lowry's method using bovine serum albumin (BSA) (Fluka) as standard. The results were expressed as mg of total protein and the enzyme specific activity was expressed as $\mu \mathrm{mol} \mathrm{min}{ }^{-1} \mathrm{mg}$ protein ${ }^{-1}$

\section{Colour determination}

Colour was evaluated with the Hunter Lab coordinates [L (lightness, 0 for black to 100 for white), a (red-green) and b (yellow-blue)] with a tristimulus colorimeter (Dr Lange Spectrocolour, Berlin, Germany) (Hunterlab, 2012). The colorimeter $\left(\mathrm{d} / 8^{\circ}\right.$ geometry, illuminant D65, $10^{\circ}$ observer) was calibrated against a standard ceramic white tile $(\mathrm{X}=84.60, \mathrm{Y}=89.46, \mathrm{Z}=93.85)$ and a standard ceramic black tile $(X=4.12$, $\mathrm{Y}=4.38, \mathrm{Z}=4.71$ ). Measurements were taken in triplicate with 5 readings each.

\section{Texture determination}

The texture of raw and processed samples was analysed using a texturometer (LFRA Texture Analyser, Brookfield) equipped with a $1.5 \mathrm{~kg}$ load cell. Based on the method reported by Taniwaki, Takahashi, Sakurai, Takada, and Nagata (2009), each leaf was sandwiched between two metal plates with a cylindrical hole in the centre (diameter $=15 \mathrm{~mm}$ ). The test speed was set at 2 $\mathrm{mm} / \mathrm{s}$ and a stainless steel probe (TA-39) with flat end, $2 \mathrm{~mm}$ diameter and $20 \mathrm{~mm}$ long was used to penetrate the sample. Peak force was used to quantify the firmness (g) of the samples. Measurements were run in triplicate.

\section{pH determination}

Two grams of raw Portuguese cabbage were homogenized (Ultra-Turrax T25 Janke and Kunkel) for $1 \mathrm{~min}$ at 13,500 rpm in $20 \mathrm{ml}$ of degassed water (Health Canada-Official Method, 1999). The extracts were obtained through agitation with a mechanical shaker (Edmund Bühler 7400 Tübingen KL2) for $30 \mathrm{~min}$. Afterwards, samples were kept in the dark for an additional hour. The supernatant was decanted and the $\mathrm{pH}$ was measured (pH meter Crison micropH 2002) in ten replicates.

\section{Data analysis}

Enzyme inactivation, colour and texture changes are well described in the literature by zero, first-order, fractional and two fraction first-order models (Anthon \& Barrett, 2002; Cruz, Vieira, \& Silva, 2006; Gonçalves, Pinheiro, Abreu, 
Brandão, \& Silva, 2007; Lau, Tang, \& Swanson, 2000; Morales-Blancas et al., 2002; Soysal \& Soylemez, 2005; Tijskens, Schijvens, \& Biekman, 2001). After preliminary analysis, a first-order reaction model (Eq. 1) was used to fit the experimental data for POD inactivation and $L$ and $b$ parameters colour changes obtained for each blanching process.

$$
C_{t}=C_{0} e^{-k t}
$$

Where $\mathrm{C}_{0}$ is the initial value and $\mathrm{C}_{t}$ the value at time t.

The temperature dependence of the rate constant (k) followed the Arrhenius behaviour (Eq. 2).

$$
k=k_{r e f} e^{\left[-\frac{E_{a}}{R}\left(\frac{1}{T}-\frac{1}{T_{r e f}}\right)\right]}
$$

A global model (Eq. 3) was obtained replacing $\mathrm{k}$ in Eq. 1 by the Arrhenius equation (Eq. 2) (Arabshahi \& Lund, 1985):

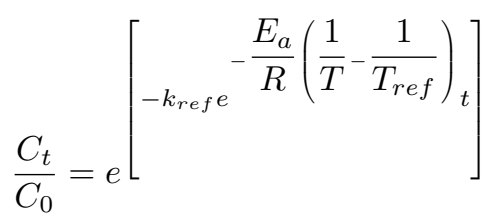

For texture and a parameter colour changes, a two fraction first-order reaction model (Eq. 4) was used to fit the experimental data.

$$
C_{t}=C_{01} e^{-k 1 t}+C_{02} e^{-k 2 t}
$$

For both fractions, it was assumed that the firstorder rate constants, $\mathrm{k}_{1}$ and $\mathrm{k}_{2}$, dependence on temperature (Eqs. 5 and 6) followed the Arrhenius law:

$$
\begin{aligned}
& k_{1}=k_{r e f 1} e \\
& k_{2}=k_{r e f 2} e \\
& {\left[-\frac{E_{a 1}}{R}\left(\frac{1}{T}-\frac{1}{T_{\text {ref }}}\right)\right]} \\
& {\left[-\frac{E_{a 2}}{R}\left(\frac{1}{T}-\frac{1}{T_{\text {ref }}}\right)\right]}
\end{aligned}
$$

A global model (Eq. 7) was obtained replacing $\mathrm{k}$ in Eq. 4 by the Arrhenius equation (Eq. 5 and
6) for both fractions.

$$
\begin{aligned}
& \left.C=C_{01} e^{\left[-k_{r e f 1} e^{-\frac{E_{a 1}}{R}\left(\frac{1}{T}-\frac{1}{T_{r e f}}\right)} t\right.}\right] \\
& \left.+C_{02} e^{\left[-k_{r e f 2} e^{-\frac{E_{a 2}}{R}\left(\frac{1}{T}-\frac{1}{T_{r e f}}\right)} t\right.}\right]
\end{aligned}
$$

Experimental data points were normalized, by dividing the values at time $\mathrm{t}\left(\mathrm{C}_{t}\right)$ by the initial value $\left(\mathrm{C}_{0}\right)$. An analysis of variance (twoway ANOVA with replication) was performed to assess the effect of blanching time-temperature (tested factors-independent variables) conditions on POD activity, colour and texture changes (dependent variables). The kinetic parameters were estimated directly from the experimental data, by performing a one-step non-linear regression analysis (using least squares estimation and Levenverg-Marquart method), fitting the global model equations 3 (first-order reaction) and 7 (two fractions first-order reaction) (Arabshahi \& Lund, 1985) and using the statistical software STATA version 10.0. The reference temperature $\left(\mathrm{T}_{\text {ref }}\right)$ was considered to be the average temperature of the experiments $\left(87.5^{\circ} \mathrm{C}\right)$ aimed at improving parameter estimation. The goodness of fit of the regression was assessed by the coefficient of determination $\left(\mathrm{R}^{2}\right)$ while normality and randomness of residuals by the predicted vs. experimental data chart; the precision of the parameters was evaluated by confidence intervals at $95 \%$.

\section{Results and Discussion}

\subsection{Peroxidase inactivation}

Raw Portuguese cabbage presented a peroxidase activity of $0.30 \pm 0.17 \mu \mathrm{mol} \mathrm{min}^{-1} \mathrm{mg}$ protein $^{-1}$ and a $\mathrm{pH}$ of $6.32 \pm 0.12$. Experimental and predicted values of the POD activity for heat only and the combined treatment are presented in Figure 1 . The results at higher temperatures, 90 and $95{ }^{\circ} \mathrm{C}$, showed similar rate of POD inactivation between heat and the combined treatment (about 100\% inactivation in the first $10 \mathrm{~s}$ 
$184 \mid$ Cruz et al.

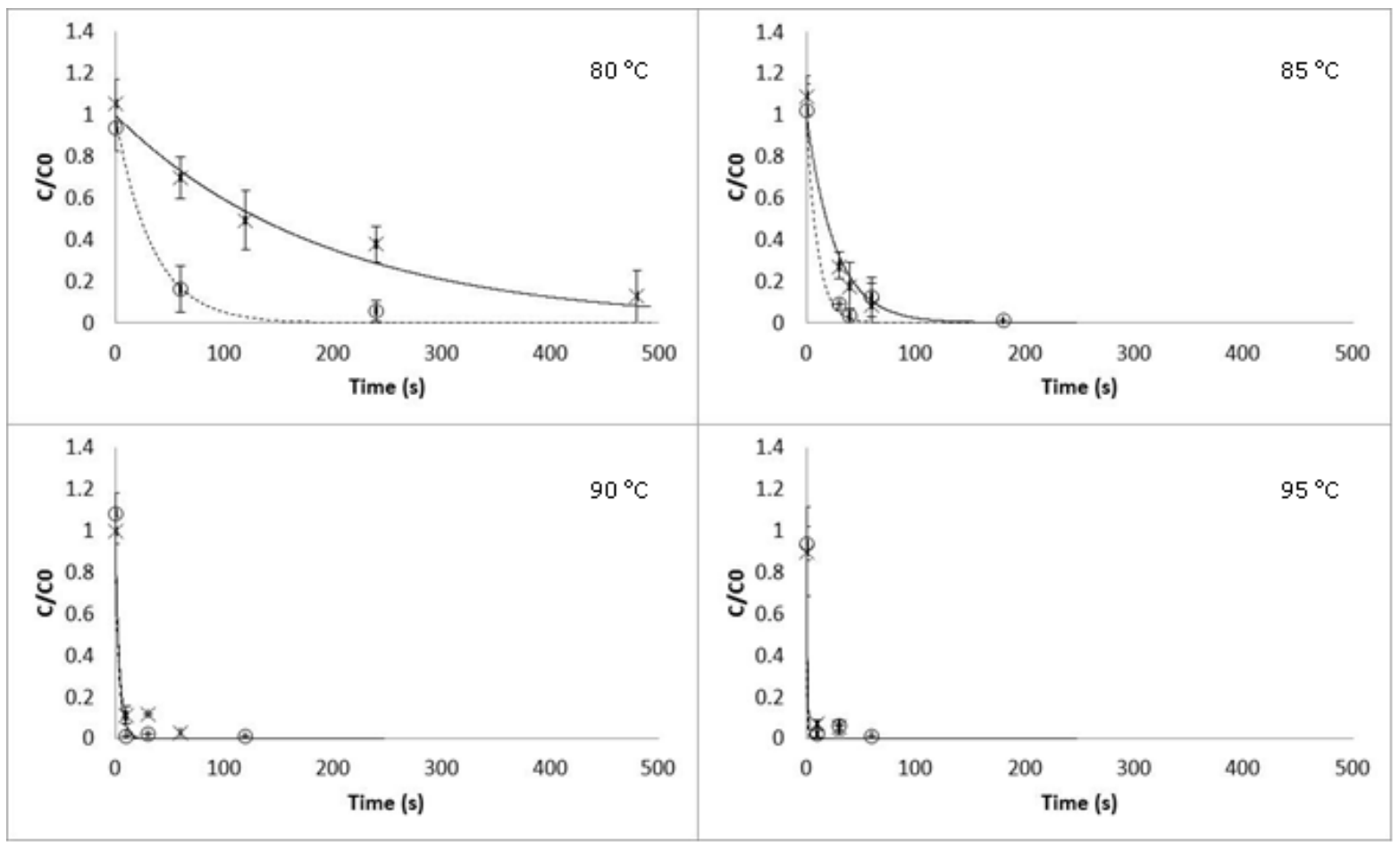

Figure 1: Effect of temperature and UV-C light over time on POD specific activity in Portuguese cabbage in the temperature range $80-95{ }^{\circ} \mathrm{C}:(\mathrm{x})$ experimental values of POD specific activity with heat blanching processes; (-) model predicted values for heat blanching processes; (o) experimental values of POD specific activity with combined UV-C light and heat blanching processes; (_--) model predicted values with combined UV-C light and heat blanching processes. Bars represent mean \pm standard deviation $(\mathrm{n}=3)$

of processing), meaning that the high temperature was the main factor for this outcome. Nevertheless, at lower temperatures $\left(80\right.$ and $85^{\circ} \mathrm{C}$ ) the combined treatment showed a higher POD inactivation rate (about 4 -fold at $80{ }^{\circ} \mathrm{C}$ and 1 min of exposure) due to the synergistic hurdle effect produced by the UV-C light followed by heat. These results were mainly due to the structural changes on the enzyme active site, leading to a lower enzyme-substrate interaction. Lamikanra, Kueneman, Ukuku, and Bett-Garber (2005) found that UV treatment increases POD activity while lowering esterase and lipase activity. In another study, Manzocco, Quarta, and Dri (2009) showed that exposure of apple derivatives to UV-C light is very effective in polyphenoloxidase inactivation. These outcomes are dependent on the applied methodologies and the different types of food matrices.

Concerning the kinetic modelling, a first-order kinetic model was well-fitted to results obtained for both blanching processes $\left(R^{2}=0.97\right.$ and $R^{2}=0.98$ in table 1 ), meaning that the enzyme inactivation could be described by this model. Other studies also proposed this model for POD inactivation, for watercress (Cruz et al., 2006), for carrots (Soysal \& Soylemez, 2005) and for broccoli (Morales-Blancas et al., 2002). Also, the temperature dependence of the rate constant followed the Arrhenius behaviour. The thermal inactivation reaction rate $\left(\mathrm{k}_{\text {ref }}\right)$ and activation energy $(E a)$ for heat and UV-C+heat blanching treatments are shown on Table 1 . The reaction rate for the combined treatment, at the refer- 
Kinetics of quality parameters of Portuguese cabbage during UV-C light and heat blanching | 185

Table 1: Kinetic parameters for quality changes in Portuguese cabbage

\begin{tabular}{|c|c|c|}
\hline & Heat blanching & UV-C and heat blanching \\
\hline \multicolumn{3}{|l|}{ Peroxidase } \\
\hline$k_{r e f}\left(s^{-1}\right)$ & $0.10 \pm 0.02$ & $0.18 \pm 0.06$ \\
\hline$E a\left(k J \mathrm{~mol}^{-1}\right)$ & $417.80 \pm 34.88$ & $255.96 \pm 49.08$ \\
\hline \multicolumn{3}{|l|}{ Colour $(L)$} \\
\hline$k_{\text {ref }}\left(s^{-1}\right)$ & $0.00041 \pm 0.00009$ & $0.00040 \pm 0.00012$ \\
\hline$E a\left(k J \mathrm{~mol}^{-1}\right)$ & $117.9 \pm 35.74$ & $63.96 \pm 49.42$ \\
\hline \multicolumn{3}{|l|}{ Colour (a) } \\
\hline$C_{01}$ & $1.62 \pm 0.13$ & $1.44 \pm 0.12$ \\
\hline$k_{r e f 1}\left(s^{-1}\right)$ & $0.0056 \pm 0.00095$ & $0.0054 \pm 0.00040$ \\
\hline$E a_{1}\left(k J m o l^{-1}\right)$ & $149.62 \pm 10.43$ & $155.33 \pm 16.75$ \\
\hline$C_{02}$ & $0.63 \pm 0.13$ & $0.45 \pm 0.18$ \\
\hline$k_{\text {ref } 2}\left(s^{-1}\right)$ & $0.082 \pm 0.038$ & $0.076 \pm 0.043$ \\
\hline$E a_{2}\left(k J \mathrm{~mol}^{-1}\right)$ & $79.98 \pm 52.41$ & $68.95 \pm 41.24$ \\
\hline \multicolumn{3}{|l|}{ Colour (b) } \\
\hline$k_{r e f}\left(s^{-1}\right)$ & $0.0021 \pm 0.0005$ & $0.0017 \pm 0.0003$ \\
\hline$E a\left(k J m^{\prime} l^{-1}\right)$ & $96.60 \pm 35.60$ & $144.95 \pm 31.11$ \\
\hline \multicolumn{3}{|l|}{ Firmness (g) } \\
\hline$C_{01}$ & $0.55 \pm 0.12$ & $0.58 \pm 0.10$ \\
\hline$k_{r e f 1}\left(s^{-1}\right)$ & $0.11 \pm 0.06$ & $0.13 \pm 0.08$ \\
\hline$E a_{1}\left(k J \mathrm{~mol}^{-1}\right)$ & $186.86 \pm 53.91$ & $140.10 \pm 67.09$ \\
\hline$C_{02}$ & $1.55 \pm 0.11$ & $1.61 \pm 0.10$ \\
\hline$k_{\text {ref } 2}\left(s^{-1}\right)$ & $0.0055 \pm 0.00098$ & $0.0067 \pm 0.00088$ \\
\hline$E a_{2}\left(k J \mathrm{~mol}^{-1}\right)$ & $135.68 \pm 12.72$ & $138.99 \pm 9.51$ \\
\hline
\end{tabular}

ence temperature, was higher $\left(0.18 \pm 0.06 \mathrm{~s}^{-1}\right)$ than the value obtained for the heat blanching treatment $\left(0.10 \pm 0.02 \mathrm{~s}^{-1}\right)$. The estimated activation energy for POD inactivation was in accordance with the ones reported by Anthon and Barrett (2002) $480 \mathrm{~kJ} \mathrm{~mol}^{-1}$ and $478 \mathrm{~kJ} \mathrm{~mol}^{-1}$ for carrot and potato. In contrast, Soysal and Soylemez (2005) reported values of $148 \mathrm{~kJ} \mathrm{~mol}^{-1}$ for POD inactivation in carrot. In another study, Cruz et al. (2006) reported activation energy values of $\mathrm{Ea}_{1}=421 \mathrm{~kJ} \mathrm{~mol}^{-1}$ and $\mathrm{Ea}_{2}=352 \mathrm{~kJ}$ $\mathrm{mol}^{-1}$ in watercress leaves, for heat-labile and heat-resistant fractions, respectively.

Moreover, Neves, Vieira, and Silva (2012) reported that UV-C light also contributed to the increase in POD inactivation rate in zucchini. The estimated kinetic parameters were $\mathrm{k}_{\text {Heat }}=7.37 \times 10^{-7}$ min- $^{-1}$ and $\mathrm{Ea}_{\text {Heat }}=925 \mathrm{~kJ}$ $\mathrm{mol}^{-1}$ and $\mathrm{k}_{\text {Heat }+U V-C}=2.42 \times 10^{-5} \mathrm{~min}^{-1}$ and $\mathrm{Ea}_{\text {Heat }+U V-C}=596 \mathrm{~kJ} \mathrm{~mol}^{-1}$.

\subsection{Colour changes}

Raw Portuguese cabbage presented values of $L, a$ and $b$ of $36.89 \pm 2.73,-7.49 \pm 1.17$ and $8.39 \pm 2.31$, respectively. At the end of each blanching process, these colour parameters did not show significant differences between treatments (ANOVA, $\mathrm{p}>0.05)$. The $L$ and $b$ colour parameters decreased in both treatments (traditional and UV$\mathrm{C}$ light followed by heat blanching), showing that the samples after blanching became slightly darker and less yellow (Fig. 2 and Fig. 4, re-

\begin{tabular}{l|l|l|l} 
IJFS | October 2016 | Volume 5 & pages 180-192
\end{tabular} 
186| Cruz et al.

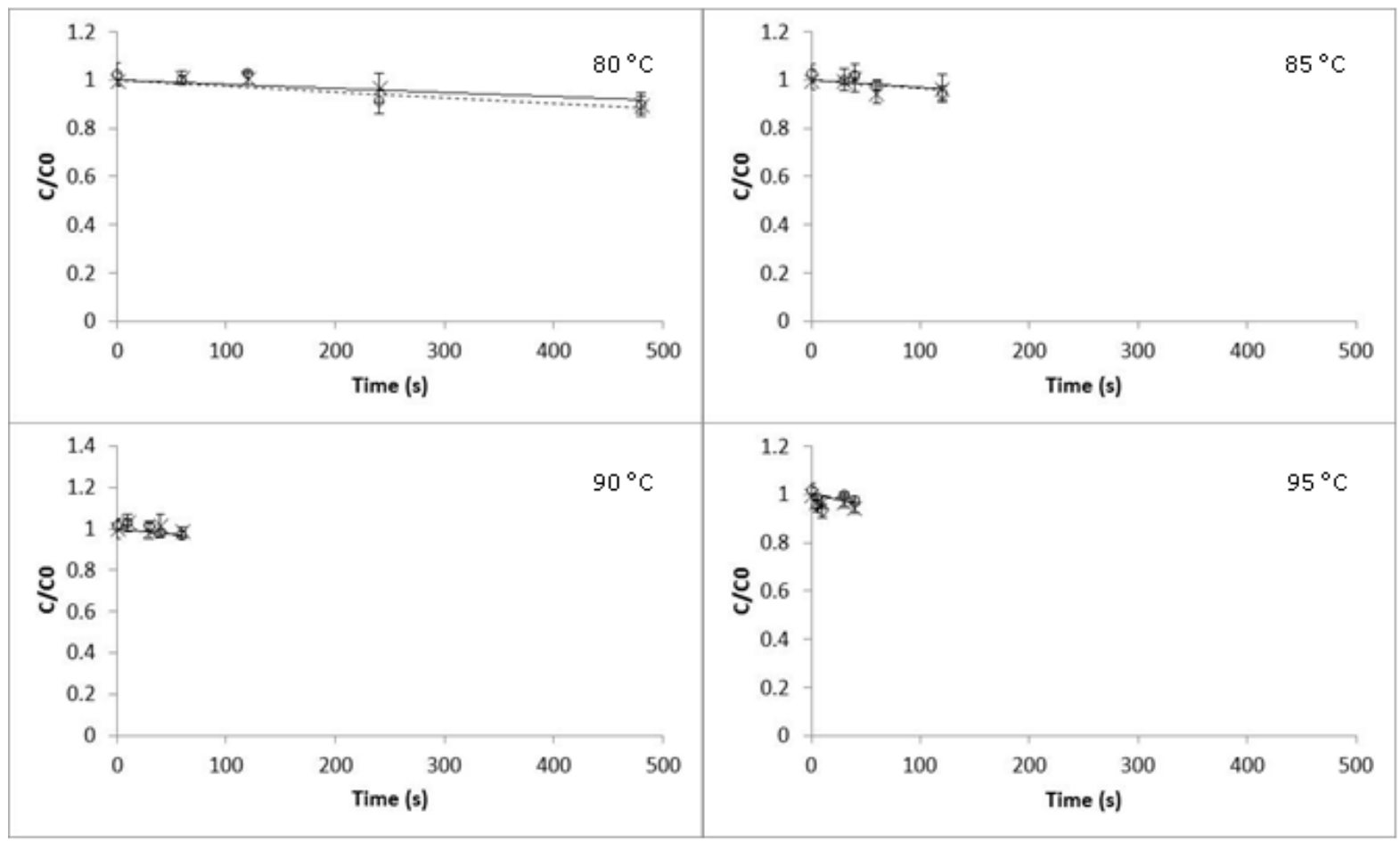

Figure 2: Effect of temperature and UV-C light over time on colour $L$ parameter in Portuguese cabbage in the temperature range $80-95^{\circ} \mathrm{C}$ : (x) experimental values of $L$ parameter with heat blanching processes; (-) model predicted values for heat blanching processes; (o) experimental values of colour $L$ parameter with combined UV-C light and heat blanching processes; (_--) model predicted values for with combined UV-C light and heat blanching processes. Bars represent mean \pm standard deviation $(\mathrm{n}=15)$

spectively). Changes in the a colour parameter showed two distinct mechanisms. First, the $a$ values increased right at the beginning of the blanching treatments (5-60 s and 80-95 ${ }^{\circ} \mathrm{C}$ ) resulting in greener samples, and then decreased after some time of exposure turning the samples less green (Fig. 3). This decrease might be related to the chlorophylls leaching out into the blanching medium and/or conversion of chlorophylls to pheophytins (Schwartz \& Vonelbe, 1983). These results are in agreement with those reported by Di Cesare, Forni, Viscardi, and Nani (2004), in which leaves of oregano also became greener after blanching. Lin and Brewer (2005) showed in a study with frozen peas that after microwave and water blanching the peas were also greener. In another study, Brewer, Begum, and Bozeman (1995) reported significant darkening of stems and florets of broccoli after microwave blanching. Tijskens et al. (2001) presented similar effects on green colour of blanched broccoli and green beans. Recently, Alvarez-Jubete et al. (2014), in a study in which white cabbage samples were blanched at $90-95{ }^{\circ} \mathrm{C}$ during $3 \mathrm{~min}$, also reported a slight decrease in the $L$ parameter. These colour changes may be related to the replacement of the gases inside the intercellular spaces by the blanching medium, altering light refraction from the cell surface (MacDougall, 2002).

In terms of kinetic modelling, a first-order model and two fractions first-order model fitted well the experimental data for $L$ and $b$ parameters and a parameter, respectively (Table 1) and the temperature dependence followed the Arrhenius behaviour. In all cases, normality and randomness 


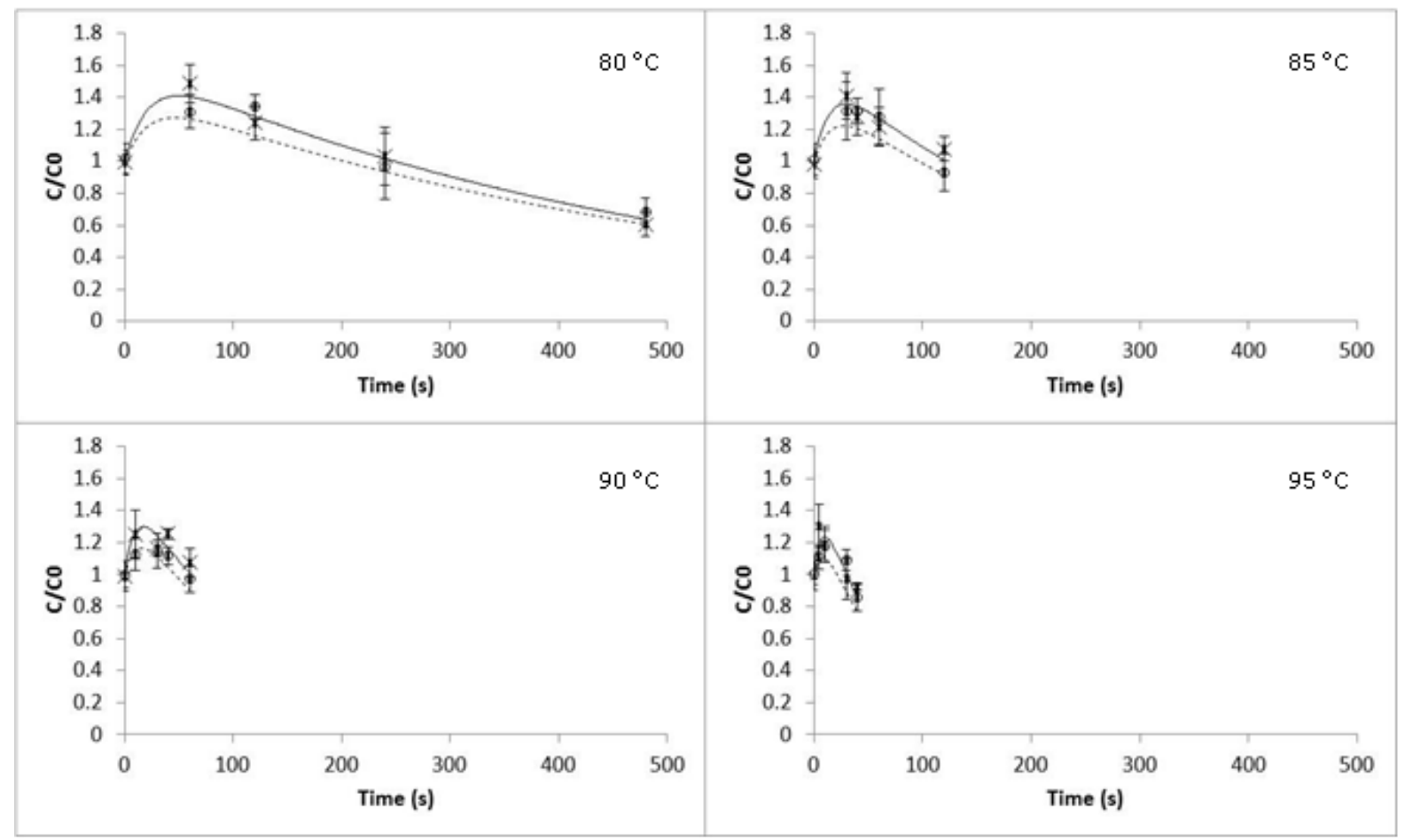

Figure 3: Effect of temperature and UV-C light over time on colour $a$ parameter in Portuguese cabbage in the temperature range $80-95^{\circ} \mathrm{C}$ : $(\mathrm{x})$ experimental values of $a$ parameter with heat blanching processes; (-) model predicted values for heat blanching processes; (o) experimental values of colour $a$ parameter with combined UV-C light and heat blanching processes; (---) model predicted values for with combined UV-C light and heat blanching processes. Bars represent mean \pm standard deviation $(\mathrm{n}=15)$

of residuals were verified, and the coefficient of determination, $\mathrm{R}^{2}$, was higher than 0.95 . No significant differences $(\mathrm{p}>0.05)$ were detected between the estimated reaction rates and activation energies at the reference temperature $(87.5$ ${ }^{\circ} \mathrm{C}$ ) for both treatments. The activation energy values for colour changes varied between 63.96 and $155.33 \mathrm{~kJ} \mathrm{~mol}^{-1}$ for $L$ and $a$ parameters in the UV-C and heat blanching treatment, respectively. The high activation energies obtained revealed that Portuguese cabbage is sensitive to the temperatures applied during the blanching process. Cruz, Vieira, and Silva (2007) presented higher activation energies for $L a b$ parameters $\left(\mathrm{Ea}_{L}=235.83 \pm 89.32 \mathrm{~kJ} \mathrm{~mol}^{-1}, \mathrm{Eaa}=187.70 \pm 160\right.$ $\mathrm{kJ} \mathrm{mol}{ }^{-1}$ and $\mathrm{Ea}_{b}=330.62 \pm 128.16 \mathrm{~kJ} \mathrm{~mol}^{-1}$ ) in thermosonicated watercress leaves. Recently, Aamir, Ovissipour, Rasco, Tang, and Sablani
(2014) determined in blanched spinach leaves $\left(65-85{ }^{\circ} \mathrm{C}\right)$ an activation energy value of 117.7 $\mathrm{kJ} \mathrm{mol}{ }^{-1}$ for colour a parameter. In another study, Gonçalves, Pinheiro, Abreu, Brandão, and Silva (2010), in blanched carrot, reported values of $\mathrm{Ea}_{L}=187.03 \pm 13.60 \mathrm{~kJ} \mathrm{~mol}^{-1}, \mathrm{Ea}_{a}=$ $186.39 \pm 10.33 \mathrm{~kJ} \mathrm{~mol}^{-1}$ and $\mathrm{Ea}_{b}=231.16 \pm 17.01$ $\mathrm{kJ} \mathrm{mol}{ }^{-1}$.

\subsection{Texture changes}

Raw Portuguese cabbage presented values of firmness of $168.17 \pm 35.42 \mathrm{~g}$. Figure 5 shows the effect of heat and UV-C light followed by heat in the firmness of the Portuguese cabbage leaves.

The firmness of the cabbage leaves showed no significant differences between blanching treatments (ANOVA, $\mathrm{p}>0.05$ ). Texture changes in 
$188 \mid$ Cruz et al.

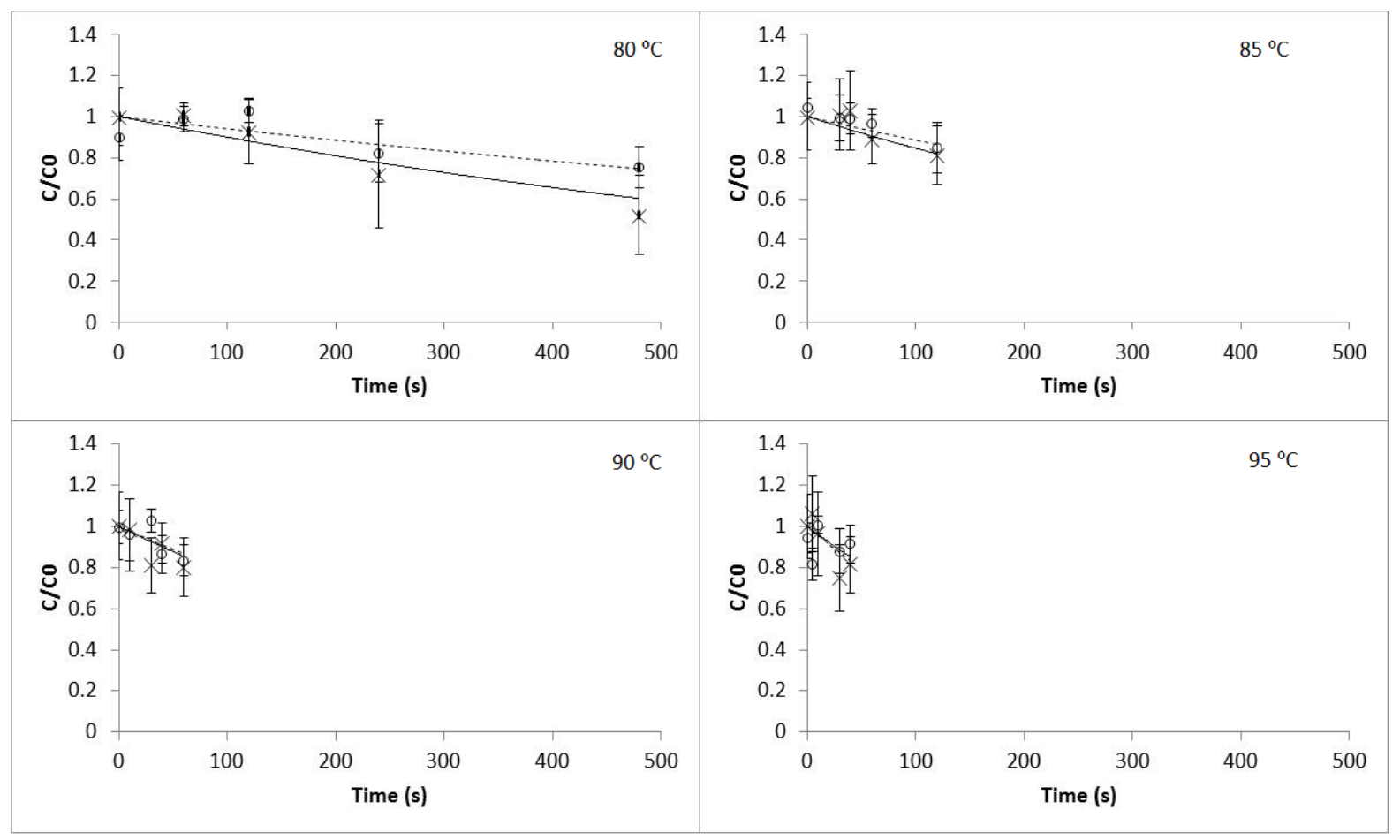

Figure 4: Effect of temperature and UV-C light over time on colour $b$ parameter in Portuguese cabbage in the temperature range $80-95{ }^{\circ} \mathrm{C}$ : $(\mathrm{x})$ experimental values of $b$ parameter with heat blanching processes; (-) model predicted values for heat blanching processes; (o) experimental values of colour $b$ parameter with combined UV-C light and heat blanching processes; (---) model predicted values for with combined UV-C light and heat blanching processes. Bars represent mean \pm standard deviation $(\mathrm{n}=15)$

Portuguese cabbage leaves also showed two distinct mechanisms. First, at short processing times $\left(5-60 \mathrm{~s}\right.$ and $\left.80-95^{\circ} \mathrm{C}\right)$, the Portuguese cabbage leaves increased in firmness to $130-140 \%$ compared to initial values. Then, the samples became softer when the processing time increased. Ni, Lin, and Barrett (2005) also reported that the firmness of a variety of vegetables (broccoli, Pak choy, Chinese cabbage, cabbage, green peppers, sugar snap peas and carrots) blanched at different temperatures $\left(55,60,65,70,75\right.$, and $\left.80{ }^{\circ} \mathrm{C}\right)$ and times of exposure $(5,15,30,45$ and $60 \mathrm{~min})$ showed between 80 and almost $200 \%$ increase in firmness compared to the blanched control (100 ${ }^{\circ} \mathrm{C}$ and 3 min.). Moreover, AnzalduaMorales, Quintero, and Balandran (1996) reported a pronounced increase in the firmness of lentils in the initial stage of blanching at $80{ }^{\circ} \mathrm{C}$ and $85{ }^{\circ} \mathrm{C}$ compared to blanching at 90 and $95{ }^{\circ} \mathrm{C}$. During thermal processing, a range of enzymatic and chemical reactions occur, which alter the texture of processed vegetables. The chemical changes, such as solubilisation and depolymerisation of pectic polysaccharides, affect the constituents of the cell wall and middle lamella, thereby resulting in a major change in the firmness of vegetables (Nisha, Singhal, \& Pandit, 2006). This increase in firmness may be the result of the availability of calcium ions for cross-link formation with adjacent pectin molecules (Latorre, de Escalada Plá, Rojas, \& Gerschenson, 2013) and also the role of pectin methyl esterase (PME), in hydrolyzing the methyl ester linkages in pectin molecules, releasing methanol and free galacturonic acid moieties. The resulting free carboxyl groups may then form cross-links between 


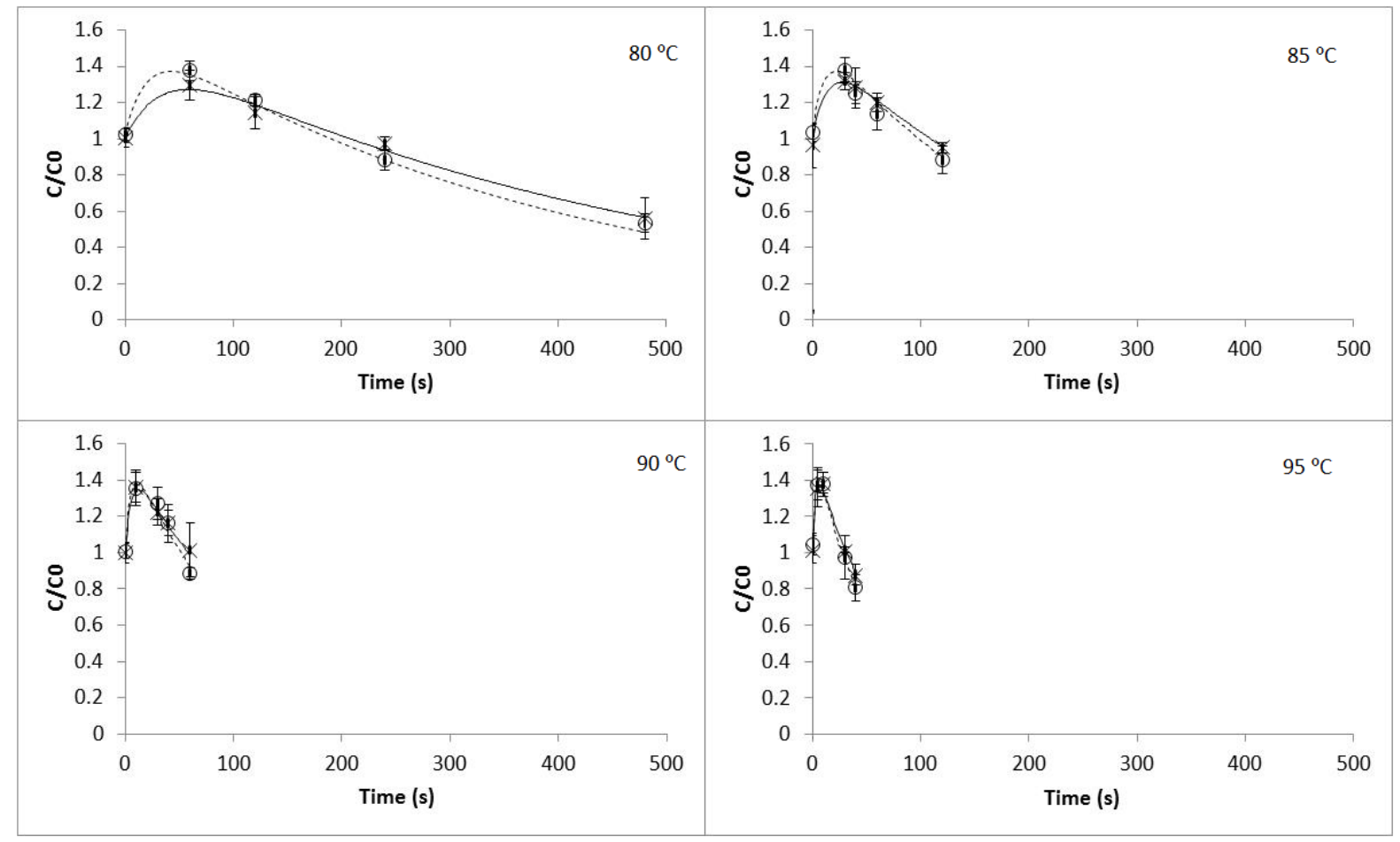

Figure 5: Effect of temperature and UV-C light over time on texture (firmness) in Portuguese cabbage in the temperature range $80-95{ }^{\circ} \mathrm{C}$ : $(\mathrm{x})$ experimental values of texture (firmness) with heat blanching processes; (-) model predicted values for heat blanching processes; (o) experimental values of texture (firmness) with combined UV-C light and heat blanching processes; (_--) model predicted values for with combined UV-C light and heat blanching processes. Bars represent mean \pm standard deviation $(n=3)$

pectin polymers through salt-bridge formation with divalent cations (particularly $\mathrm{Ca} 2+$ ) naturally present in the tissues (Puri, Solomos, \& Kramer, 1982; Ni et al., 2005). At higher temperatures the permeability of membranes is increased, resulting in passive efflux of solutes and an irreversible reduction of cell turgor well before membranes are completely destroyed (De Belie, Herppich, \& De Baerdemaeker, 2000).

A two fractions first-order model fitted well the experimental data (Table 1) and the temperature dependence of firmness also followed the Arrhenius behaviour. The estimated reaction rates and activation energies at the reference temperature $\left(87.5^{\circ} \mathrm{C}\right)$ for both treatments where very similar $\left(\mathrm{R}^{2}\right.$ and adjusted $\mathrm{R}^{2}$ presented values of 0.99 for both treatments). The activation energy values for texture changes, for each fraction, varied be- tween 135.68 and $186.86 \mathrm{~kJ} \mathrm{~mol}^{-1}$. Jaiswal et al. (2012) reported a lower activation energy value of $33.88 \mathrm{~kJ} \mathrm{~mol}^{-1}$ for Irish York cabbage blanched at temperatures varying between $80-100{ }^{\circ} \mathrm{C}$ during 2-14 min. Huang and Bourne (1983) reported activation energies ranging from 21.35 to 146.50 $\mathrm{kJ} \mathrm{mol}^{-1}$ for different vegetables. (AnzalduaMorales et al., 1996) reported activation energy values of $107.50 \mathrm{~kJ} \mathrm{~mol}^{-1}, 147.40 \mathrm{~kJ} \mathrm{~mol}^{-1}$ and $210.50 \mathrm{~kJ} \mathrm{~mol}^{-1}$ for the texture of blanched (80$95^{\circ} \mathrm{C}$ ) white beans, chick peas and broad beans, respectively. Lau et al. (2000) studied the kinetics of textural changes in green asparagus during thermal treatments $\left(70-98{ }^{\circ} \mathrm{C}\right)$ and reported an activation energy value of $100.6 \mathrm{~kJ} \mathrm{~mol}^{-1}$. In another study Gonçalves et al. (2007) reported an activation energy value of $72.21 \mathrm{~kJ} \mathrm{~mol}^{-1}$ in blanched pumpkin $\left(75-95^{\circ} \mathrm{C}\right)$. Vu et al. (2004) re- 
ported an activation energy of $117.6 \mathrm{~kJ} \mathrm{~mol}^{-1}$ in blanched carrot $\left(80-110{ }^{\circ} \mathrm{C}\right)$. Possibly, these variations are related to the differences in the raw material, modelling methodologies and the temperature ranges used in each study.

In commercial scenarios, to obtain vegetables that maintain optimum quality during storage, a reduction of $90 \%$ of the POD activity after blanching is recommended (Bahçeci, Serpen, Gokmen, \& Acar, 2005). In the present study, the UV-C light followed by heat treatment, for example at $80{ }^{\circ} \mathrm{C}$, required only $1.30 \mathrm{~min}$ to reduce $90 \%$ of the POD activity, while maintaining $98 \%$ of lightness and $92 \%$ of yellowness and increasing green colour (130\%) and the firmness (125\%) of the Portuguese cabbage leaves. On the other hand, the traditional heat blanching treatment at $80{ }^{\circ} \mathrm{C}$ requires $7.4 \mathrm{~min}$ to reduce $90 \%$ of the enzyme activity. This treatment reduces lightness, greenness, yellowness and firmness to $92 \%, 68 \%, 62 \%$ and $61 \%$ of initial values, respectively. Therefore, for the inactivation of this enzyme, the alternative treatment may be used to minimize colour and texture changes, since processing times can be reduced. It should be also remarked that instead of promoting colour and texture degradation, the applied treatment at lower short processing times led to greener and firmer Portuguese cabbage leaves.

\section{Conclusions}

The combination of UV-C light followed by heat blanching treatment at 80 and $85{ }^{\circ} \mathrm{C}$ was shown to significantly shorten the treatment time needed to inactivate POD in Portuguese cabbage. Thus, it can be considered effective to be used as a hurdle prior to a heat blanching treatment and provide a practical alternative to the traditional blanching treatments for inactivating POD in Portuguese cabbage. Moreover, this combined treatment was revealed to be a better blanching process due to the good quality retention in the treated produce. The present findings will help optimize the Portuguese cabbage blanching conditions by heat blanching combined with UV-C light treatment.

\section{References}

Aamir, M., Ovissipour, M., Rasco, B., Tang, J., \& Sablani, S. (2014). Seasonality of the thermal kinetics of color changes in whole spinach (spinacia oleracea) leaves under pasteurization conditions. International Journal of Food Properties, 17(9), 2012-2024. doi:10 . $1080 / 10942912$. 2013. 779701

Aguilar, C. N., Rodriguez-Herrera, R., Montanez-Saenz, J. C., Reyes-Vega, M. D., \& Contreras-Esquivel, J. C. (2004). Blanching at low temperatures: a thermal bioprocess applied to fruits and vegetables to improve textural quality. Food Science and Biotechnology, 13(1), 104-108.

Allende, A. \& Artes, F. (2003). Uv-c radiation as a novel technique for keeping quality of fresh processed 'lollo rosso' lettuce. Food Research International, 36(7), 739746. doi:10.1016/S0963-9969(03)00054-1

Alvarez-Jubete, L., Valverde, J., Patras, A., Mullen, A. M., \& Marcos, B. (2014). Assessing the impact of high-pressure processing on selected physical and biochemical attributes of white cabbage (brassica oleracea 1. var. capitata alba). Food and Bioprocess Technology, 7(3), 682-692. doi:10. 1007/s11947-013-1060-5

Anthon, G. E. \& Barrett, D. M. (2002). Kinetic parameters for the thermal inactivation of quality-related enzymes in carrots and potatoes. Journal of Agricultural and Food Chemistry, 50(14), 4119-4125. doi:10. 1021/jf011698i

AnzalduaMorales, A., Quintero, A., \& Balandran, R. (1996). Kinetics of thermal softening of six legumes during cooking. Journal of Food Science, 61(1), 167-170. doi:10. 1111/j.1365-2621.1996.tb14751.x

Arabshahi, A. \& Lund, D. B. (1985). Considerations in calculating kinetic parameters from experimental data. Journal of Food Process Engineering, 7(4), 239-251.

Bahçeci, K. S., Serpen, A., Gokmen, V., \& Acar, J. (2005). Study of lipoxygenase and peroxidase as indicator enzymes in green beans: change of enzyme activity, ascorbic acid and chlorophylls during frozen storage. 
Journal of Food Engineering, 66(2), 187192. doi:10.1016/j.jfoodeng.2004.03.004

Brewer, M. S., Begum, S., \& Bozeman, A. (1995). Microwave and conventional blanching effects on chemical, sensory, and color characteristics of frozen broccoli. Journal of Food Quality, 18(6), 479-493. doi:10.1111/ j.1745-4557.1995.tb00398.x

Cruz, R. M. S., Vieira, M. C., \& Silva, C. L. M. (2006). Effect of heat and thermosonication treatments on peroxidase inactivation kinetics in watercress (nasturtium officinale). Journal of Food Engineering, 72(1), 8-15. doi:10.1016/j.jfoodeng.2004.11.007

Cruz, R. M. S., Vieira, M. C., \& Silva, C. L. M. (2007). Modelling kinetics of watercress (nasturtium officinale) colour changes due to heat and thermosonication treatments. Innovative Food Science 8 Emerging Technologies, 8(2), 244-252. doi:10.1016/j.ifset. 2007.01.003

De Belie, N., Herppich, W., \& De Baerdemaeker, O. (2000). A kinetic model for turgor loss in red cabbage cells during mild heat treatment. Journal of Plant Physiology, 157(3), 263-272.

Di Cesare, L. F., Forni, E., Viscardi, D., \& Nani, R. C. (2004). Influence of drying techniques on the volatile phenolic compounds, chlorophyll and colour of oregano (origanum vulgare 1. ssp, prismaticum gaudin). Italian Journal of Food Science, 16(2), 165-175.

Ganjloo, A., Rahman, R. A., Osman, A., Bakar, J., \& Bimakr, M. (2011). Kinetics of crude peroxidase inactivation and color changes of thermally treated seedless guava (psidium guajava 1.) Food and Bioprocess Technology, 4(8), 1442-1449. doi:10 . 1007 / s11947-009-0245-4

Gonçalves, E. M., Pinheiro, J., Abreu, M., Brandão, T. R. S., \& Silva, C. L. M. (2007). Modelling the kinetics of peroxidase inactivation, colour and texture changes of pumpkin (cucurbita maxima l.) during blanching. Journal of Food Engineering, 81 (4), 693-701.

Gonçalves, E. M., Pinheiro, J., Abreu, M., Brandão, T. R. S., \& Silva, C. L. M. (2010). Carrot (daucus carota l.) peroxidase inactivation, phenolic content and physical changes kinetics due to blanching. Journal of Food Engineering, 97(4), 574-581. doi:10.1016/j.jfoodeng.2009.12.005

Health Canada-Official Method. (1999). T-310Determination of whole tobacco $\mathrm{pH}$. Ottawa, Canada.

Huang, Y. T. \& Bourne, M. C. (1983). Kinetics of thermal softening of vegetables. Journal of Texture Studies, 14 (1), 1-9. doi:10.1111/ j.1745-4603.1983.tb00329.x

Hunterlab. (2012). Measuring Colour using Hunter L, a, b versus CIE 1976 L*a*b*. AN 1005.00, 1-4.

Jaiswal, A. K., Gupta, S., \& Abu-Ghannam, N. (2012). Kinetic evaluation of colour, texture, polyphenols and antioxidant capacity of irish york cabbage after blanching treatment. Food Chemistry, 131(1), 63-72. doi:10.1016/j.foodchem.2011.08.032

Koutchma, T. (2009). Advances in ultraviolet light technology for non-thermal processing of liquid foods. Food and Bioprocess Technology, 2(2), 138-155. doi:10.1007/s11947008-0178-3

Lamikanra, O., Kueneman, D., Ukuku, D., \& Bett-Garber, K. L. (2005). Effect of processing under ultraviolet light on the shelf life of fresh-cut cantaloupe melon. Journal of Food Science, 70(9), C534-C539.

Latorre, M. E., de Escalada Plá, M. F., Rojas, A. M., \& Gerschenson, L. N. (2013). Blanching of red beet (beta vulgaris 1. var. conditiva) root. effect of hot water or microwave radiation on cell wall characteristics. LWT-Food Science and Technology, 50(1), 193-203.

Lau, M. H., Tang, J., \& Swanson, B. G. (2000). Kinetics of textural and color changes in green asparagus during thermal treatments. Journal of Food Engineering, 45(4), 231-236. doi:10 . 1016 / S0260 - 8774(00 ) 00069-8

Lin, S. \& Brewer, M. S. (2005). Effects of blanching method on the quality characteristics of frozen peas. Journal of Food Quality, 28(4), 350-360. doi:10.1111/j.1745-4557. 2005.00038.x

MacDougall, D. B. (2002). Colour in food: improving quality. Woodhead Publishing. 
Manzocco, L., Dri, A., \& Quarta, B. (2009). Inactivation of pectic lyases by light exposure in model systems and fresh-cut apple. Innovative Food Science 8 Emerging Technologies, 10(4), 500-505. doi:10.1016/j.ifset. 2009.06.002

Manzocco, L., Quarta, B., \& Dri, A. (2009). Polyphenoloxidase inactivation by light exposure in model systems and apple derivatives. Innovative Food Science \& Emerging Technologies, 10(4), 506-511. doi:10.1016/ j.ifset.2009.02.004

Morales-Blancas, E. F., Chandia, V. E., \& Cisneros-Zevallos, L. (2002). Thermal inactivation kinetics of peroxidase and lipoxygenase from broccoli, green asparagus and carrots. Journal of Food Science, 67(1), 146-154. doi:10.1111/j. 1365-2621.2002. tb11375.x

Nagodawithana, T. \& Reed, G. (1993). Enzymes in food processing. (3rd ed., 13, pp. 158162). London: Academic Press, Inc. Harcourt Brace \& Company.

Neves, F. I. G., Vieira, M. C., \& Silva, C. L. M. (2012). Inactivation kinetics of peroxidase in zucchini (cucurbita pepo l.) by heat and uv-c radiation. Innovative Food Science \& Emerging Technologies, 13, 158162. doi:10.1016/j.ifset.2011.10.013

Ni, L., Lin, D., \& Barrett, D. (2005). Pectin methylesterase catalyzed firming effects on low temperature blanched vegetables. Journal of Food Engineering, 70(4), 546556. doi:10.1016/j.jfoodeng.2004.10.009

Nisha, P., Singhal, R. S., \& Pandit, A. B. (2006). Kinetic modelling of texture development in potato cubes (solanum tuberosum 1.), green gram whole (vigna radiate l.) and red gram splits (cajanus cajan 1.) Journal of Food Engineering, 76(4), 524-530. doi:10. 1016/j.jfoodeng.2005.05.054

Patras, A., Tiwari, B. K., \& Brunton, N. P. (2011). Influence of blanching and low temperature preservation strategies on antioxidant activity and phytochemical content of carrots, green beans and broccoli. $L W T$ Food Science and Technology, 44(1), 299306. doi:10.1016/j.lwt.2010.06.019

Puri, A., Solomos, T., \& Kramer, A. (1982). Partial-purification and characterization of potato pectinesterase. Food Chemistry, 8(3), 203-213. doi:10.1016/0308-8146(82) 90042-5

Schwartz, S. J. \& Vonelbe, J. H. (1983). Kinetics of chlorophyll degradation to pyropheophytin in vegetables. Journal of Food Science, 48(4), 1303-1306. doi:10.1111/ j . 1365-2621.1983.tb09216.x

Soysal, C. \& Soylemez, Z. (2005). Kinetics and inactivation of carrot peroxidase by heat treatment. Journal of Food Engineering, 68(3), 349-356. doi:10.1016/j.jfoodeng. 2004.06.009

Szymanek, M. (2011). Effects of blanching on some physical properties and processing recovery of sweet corn cobs. Food and Bioprocess Technology, 4(7), 1164-1171. doi:10. 1007/s11947-009-0246-3

Taniwaki, M., Takahashi, M., Sakurai, N., Takada, A., \& Nagata, M. (2009). Effects of harvest time and low temperature storage on the texture of cabbage leaves. Postharvest Biology and Technology, 54(2), 106110. doi:10.1016/j.postharvbio.2009.06.004

Tijskens, L. M. M., Schijvens, E. P. H. M., \& Biekman, E. S. A. (2001). Modelling the change in colour of broccoli and green beans during blanching. Innovative Food Science and Emerging Technologies, 2(4), 303-313.

Vu, T. S., Smout, C., Sila, D. N., LyNguyen, B., Van Loey, A. M. L., \& Hendrickx, M. E. G. (2004). Effect of preheating on thermal degradation kinetics of carrot texture. Innovative food science $\&$ emerging technologies, 5(1), 37-44. 